\title{
"Diberi air gula... awalnya nangis menjadi diam, karena kenyang, gak lemas, daya tahan tubuhnya meningkat"; Studi Pola Asupan pada Bayi
}

\section{"Given sugar water ... at first the cry became silent, because it was full, not limp, its endurance increased"; Study of Patterns of Infant Intake}

\author{
Mila Syahriyatul Maghfiroh ${ }^{1}$, Agung Dwi Laksono $^{2 *}$
}

\begin{abstract}
ABSTRAK
Latar Belakang: Bayi adalah masa yang rentan terhadap masalah kesehatan dan gizi. WHO menyatakan bahwa $60 \%$ kematian anak balita disebabkan oleh keadaan kurang gizi. Dari jumlah tersebut, dua per tiga diantaranya disebabkan oleh pemberian makan saat bayi yang kurang tepat.

Tujuan: untuk menggambarkan pola asupan pangan pada bayi di Desa Kepung, Kabupaten Kediri.

Metode: Studi didesain secara kualitatif dengan pendekatan etnografi. Pengumpulan data dilakukan dengan menggunakan metode wawancara mendalam dan observasi partisipatif. Studi dilakukan di Desa Kepung, Kediri, Jawa Timur. Proses pengumpulan data dilakukan oleh peneliti dengan tinggal bersama target selama 6 bulan.

Hasil: Pola asupan pada bayi usia 0-6 bulan di Desa Kepung tidak hanya diberikan ASI saja, tapi diberikan makanan berupa air gula, susu formula, dan pisang kepok. Saat ibu atau pengasuh merasa bahwa bayi masih lapar, maka akan diberikan asupan pangan selain ASI tersebut. Praktik pemberian makanan tersebut tidak terlepas dari pengaruh kepercayaan yang turun-temurun, yang mana air gula diyakini dapat membuat bayi tidak rewel karena bayi menjadi kenyang dan menyehatkan.

Kesimpulan: Pola asupan pada bayi di Desa Kepung sangat bervariasi. Tidak hanya ASI, bayi juga sudah diberi makanan orang dewasa yang dilembutkan. Masyarakat di Desa Kepung juga memiliki kebiasaan memberikan bayinya air gula.
\end{abstract}

Kata Kunci: studi kualititatif, etnografi, perspektif masyarakat, keyakinan kesehatan.

\section{ABSTRACT}

Background: Babies were vulnerable to health and nutrition problems. WHO states that $60 \%$ of deaths of children under five were caused by malnutrition. Of these, two-thirds of them were caused by improper feeding of babies.

Objective: to describe patterns of food intake in infants in Kepung Village, Kediri District.

Methods: The study was designed qualitatively with an ethnographic approach. Data collection was performed using indepth interviews and participatory observation. The study was conducted in Kepung Village, Kediri, East Java. The process of collecting data was done by researchers by staying with the target for 6 months.

Results: The pattern of intake in infants aged 0-6 months in Kepung Village was not only given breast milk but was given food in the form of formula milk, sugar water and 'kepok' banana. When the mother or caregiver feels that the baby was still hungry, it will be given food intake other than the milk. The practice of feeding was inseparable from the influence of hereditary belief, where sugar water was believed to make the baby not fussy because the baby becomes full and healthy. Conclusion: The pattern of intake in infants in Kepung Village was very varied. Not only breast milk, babies have also been given mashed up adult food. People in Kepung Village also have a habit of giving their babies sugar water.

Keyword: qualitative study, ethnography, community perspective, health belief

\footnotetext{
*Korespondensi

Agung Dwi Laksono

Email: agung.dwi.laksono-2016@fkm.unair.ac.id

Pusat Penelitian dan Pengembangan Humaniora dan Manajemen Kesehatan, Kementerian Kesehatan RI.JI. Percetakan Negara 29, Jakarta, Indonesia

${ }^{1}$ Perhimpunan Sarjana dan Profesional Kesehatan Indonesia Pengda Jawa Timur, Surabaya, Indonesia.
} 


\section{PENDAHULUAN}

Bayi adalah masa yang rentan terhadap masalah kesehatan dan gizi. Karena di masa bayi inilah periode tumbuh kembang anak akan berlangsung sangat cepat dan optimal, baik perkembangan untuk intelegensi maupun fisiknya. Oleh karena itu, pada masa ini biasa disebut dengan masa keemasan (golden period). Periode emas ini akan terwujud apabila bayi mendapatkan asupan gizi sesuai dengan kebutuhannya secara optimal. Pada bayi, kekurangan gizi akan menimbulkan gangguan pertumbuhan dan perkembangan yang apabila tidak diatasi secara dini akan berlanjut hingga dewasa ${ }^{1}$. Organisasi Kesehatan Sedunia (World Health Organization/WHO) menyatakan bahwa 60\% kematian anak balita disebabkan oleh keadaan kurang gizi. Dari jumlah tersebut, dua per tiga diantaranya disebabkan oleh pemberian makan yang kurang tepat ${ }^{2,3}$.

Berdasarkan hasil Riset Kesehatan Dasar (Riskesdas) 2018, gizi kurang dan buruk serta balita pendek dan sangat pendek (stunting) pada balita di Indonesia masih menjadi masalah. Prevalensi balita yang mengalami masalah gizi kurang dan buruk pada tahun 2019 mencapai 17,7\%, sedangkan prevalensi stunting pada balita mencapai 30,8\%. Jika dibandingkan dengan target Rencana Pembangunan Jangka Menengah Nasional/RPJMN 2019, prevalensi gizi kurang dan buruk pada balita serta stunting pada baduta tersebut masih di atas target RPJMN 2019 yaitu 17\% untuk gizi kurang dan buruk. Situasi permasalahan gizi bayi atau balita di Jawa Timur hampir sama dengan kondisi secara nasional, untuk gizi kurang dan buruk mencapai $16,8 \%$. Bahkan untuk angka prevalensi stunting Jawa Timur lebih tinggi dibandingkan angka prevalensi nasional yaitu $32,81 \%$. Terdapat 12 kabupaten/kota di Jawa Timur yang menjadi lokus stunting, yakni salah satunya adalah Kabupaten Kediri dengan prevalensi $29,4 \%{ }^{4}$. Kecamatan Kepung merupakan salah satu wilayah yang menjadi prioritas penurunan angka stunting di wilayah Kabupaten Kediri.

Pemberian makanan yang kurang tepat atau terlalu dini pada bayi merupakan masalah yang umum dan sering terjadi di masyarakat wilayah pedesaaan. Fakta empiris di lapangan menemukan bahwa praktik pemberian makanan yang kurang tepat disebabkan karena banyaknya ibu balita yang bekerja. Kondisi tersebut menyebabkan pola pengasuhan yang dilakukan oleh nenek atau saudara terdekat,sehingga pola makan yang diberikan kepada balitanya sesuai dengan kemauan nenek, yang berdasarkan kebiasaan turun temurun keluarga. Kondisi tersebut didukung dengan karakteristik keluarga di Desa Kepung yang seringkali masuk dalam golongan keluarga besar (extended family), atau tinggal satu rumah dengan keluarga lain.

Fakta empiris lain, jika bayi diasuh sendiri oleh ibu, sering kali pemahaman yang dimiliki tentang makanan pendamping ASI tidak sesuai dengan umur, namun berdasar pada konsep si ibu sendiri. Konsep tersebut merupakan gabungan antara pengetahuan ibu dan internalisasi perilaku-perilaku sebelumnya yang diyakini, dilihat dan atau dialami oleh individu dari orang tua dan masyarakat. Berdasarkan pengalaman, selama ini ibu balita melakukan pola pemberian makanan tersebut, dan terbukti tidak menimbulkan dampak langsung pada balitanya. Hal ini memicu ibu balita untuk mengulang kembali cara tersebut, dan dijadikan sebagai sebuah pengalaman yang menjadi sumber pengetahuan ${ }^{5}$.

Beberapa hasil penelitian menemukan bahwa jenis asupan makanan selain ASI yang sering diberikan kepada bayi usia 0-6 bulan di berbagai wilayah antara lain air kelapa hijau muda, air madu, air kopi, susu formula, air tajin, air gula, larutan sagu, biskuit bayi, pisang yang dilembutkan, bubur susu, makanan lunak dan biskuit bayi. Alasan yang diberikan seringkali karena dipercaya dapat membersihkan pencernaan dan memperbaiki kekebalan tubuh balita. Selain itu pemberian makanan tersebut juga dimaksudkan agar anak kenyang dan tidak rewel atau tenang ${ }^{6,7}$.

Fenomena pemberian minuman dan makanan selain ASI sejak bayi lahir sampai usia 6 bulan, menyebabkan gangguan pencernaan pada bayi yang dapat mengakibatkan bayi sakit perut dan diare atau mencret. Jika bayi sakit, berakibat pada turunnya nafsu makan, sehingga bayi kurang mendapatkan asupan gizi yang cukup. Hal tersebut dapat mengakibatkan gangguan pertumbuhan balita menjadi kurang gizi. Jika kondisi tersebut berlangsung terus menerus maka bayi akan kekurangan zat gizi yang dibutuhkan tubuh, sehingga dapat menghambat pertumbuhan ${ }^{6,8}$. Berdasarkan latar belakang, maka tujuan dari penelitian ini adalah untuk menggambarkan pola asupan pada bayi di Desa Kepung, Kecamatan Kepung, Kabupaten Kediri, Jawa Timur.

\section{METODE}

Desain

Studi didesain secara kualitatif dengan pendekatan etnografi. Desain kualitatif sangat berguna ketika tujuan penelitian dilakukan untuk memahami, menemukan dan memaknai suatu fenomena. Pengumpulan data dilakukan dengan menggunakan metode wawancara mendalam dan observasi partisipatif. Wawancara mendalam kualitatif sangat berguna untuk menguji pendapat informan dan pengalaman pribadi ${ }^{9}$. Observasi partisipatif untuk mendapatkan gambaran utuh, apakah perilaku yang diakui juga merupakan perilaku dalam keseharian. Selain itu juga sebagai metode triangulasi untuk konfirmasi hasil wawancara.

Studi dilakukan di Desa Kepung, Kecamatan Kepung, Kabupaten Kediri, Jawa Timur. Proses pengumpulan data dilakukan oleh peneliti dengan tinggal bersama target (lived in). Ini harus dilakukan dalam penelitian dengan desain etnografi sehingga peneliti dapat melihat dan memahami masalah sesuai dengan konteks aslinya ${ }^{10}$. Peneliti lived in di lokasi penelitian selama enam bulan (Juni-November 2019).

Triangulasi data dilakukan untuk memastikan validitas data ${ }^{11,12}$. Triangulasi dilakukan dengan konfirmasi berdasarkan dua metode pengumpulan data yang berbeda dan pengumpulan informasi yang sama pada beberapa informan yang berbeda ${ }^{13}$.

\section{Informan}

Dalam studi ini informan ditentukan secara purposif. Informan diambil sesuai dengan substansi tujuan penelitian. Hanya informan kunci orang tua dan 
pengasuh bayi berumur kurang dari satu tahun, serta tokoh masyarakat yang memahami praktik pemberian asupan pada bayi. Secara detail karakteristik informan dapat dilihat pada tabel 1.

\section{Analisis Data}

Wawancara mendalam dilakukan dengan bantuan alat perekam. Hasil wawancara ditranskrip secara verbatim. Peneliti merefleksikan apa yang dicatat dalam buku harian itu setiap selesai wawancara. Dengan analisis tematik, hasil refleksi kemudian dikembangkan menjadi tema sesuai dengan konteks lapangan ${ }^{10}$. Selanjutnya, hasil rekaman dan transkripsi kata demi kata diberi kode sesuai dengan tema-tema ini.

\section{HASIL DAN PEMBAHASAN \\ Konteks Wilayah}

Desa Kepung terletak di bagian timur Kabupaten Kediri, dan menjadi bagian dari Kecamatan Kepung. Desa Kepung adalah desa terluas di Kabupaten Kediri, dengan luas wilayah $1.243 \mathrm{Ha}$ dan berada di lereng gunung dengan ketinggian \pm 305 mdpl. Pemerintahan Desa Kepung dibagi menjadi 11 dusun. Desa ini memiliki jarak ke ibukota kecamatan sepanjang $2 \mathrm{Km}$ dan jarak desa ke ibukota kabupaten sepanjang 40 $\mathrm{Km}$.

Tabel 1. Karakteristik Informan

\begin{tabular}{lc}
\hline \multicolumn{1}{c}{ Informan } & Jumlah \\
\hline Gender & $\mathbf{2 1}$ \\
Perempuan & 16 \\
Laki-laki & 5 \\
\hline Peran & $\mathbf{2 1}$ \\
Ibu bayi & 6 \\
Bapak bayi & 2 \\
Pengasuh (nenek bayi) & 4 \\
Tokoh masyarakat & 3 \\
Kader kesehatan & 4 \\
Tenaga kesehatan & 2 \\
\hline Usia & $\mathbf{2 1}$ \\
Produktif (15 - 49 tahun) & 15 \\
Lanjut usia (> 50 tahun) & 6 \\
\hline
\end{tabular}

Sumber: Data primer, tahun pengambilan data

Pada tahun 2019 jumlah penduduk di Desa Kepung mencapai 16.498 jiwa, dengan jumlah kepala keluarga sebanyak 4.788. Berdasarkan tingkat pendidikan, penduduk Desa Kepung mayoritas hanya lulus SD dan SMP. Sebagian besar penduduk bermata pencaharian sebagai buruh tani dan petani. Berdasarkan data desa, tingkat kesejahteraan keluarga didominasi oleh kelompok keluarga pra sejahtera dan sejahtera 1.

\section{Pola Pemberian Makanan pada Bayi}

Pemerintah menganjurkan bayi pada usia 0-6 bulan hanya diberikan Air Susu Ibu saja (ASI Eksklusif). Secara empiris bayi usia 0-6 bulan di Desa Kepung tidak hanya diberikan ASI saja. Bayi pada usia tersebut sudah mendapatkan susu formula, air gula, dan sesekali diberikan pisang kepok. Beragam alasan dan latar belakang yang didapatkan mengenai pola asupan tersebut;

“...ASI-ne medale kedik, paling mergo kondisine ibue mboten karuan mbak. Niki yugo kulo ketatalan hamil disek, terus keluargane bapak e niku mboten purun ngakoni lek iki cucu ko anak e. Dadi yo jik sepasar PN (balita) iki wes ditinggal karo ibuke, tumut kulo terus..., ibue kan tumut bojone teng morotuone, dadi mbedino mimike yo banyu gulo iku karo kadang tak dulang pisang..."

(ASI-nya keluarnya sedikit, mungkin karena kondisi ibunya yang tidak karuan. Ini anak saya hamil duluan, terus keluarga laki-laki itu tidak mau mengakui kalau cucu saya itu anaknya. Jadi ya masih lima hari PN itu sudah ditinggal ibunya, ikut saya terus, ibunya kan ikut suaminya di mertuanya, jadi setiap hari yang minumnya air gula itu sama terkadang saya suapi pisang)

( $\mathrm{S}$, ibu balita, 48 tahun)

Jarak kehamilan yang terlalu dekat juga menjadi salah satu alasan bayi 0-6 bulan di Desa Kepung tidak mendapatkan ASI Eksklusif. Pada saat bayi masih berusia sekitar satu bulan, ibu bayi sudah mengandung lagi (kesundulan, istilah dalam bahasa Jawa). Kondisi ini membuat ibu merasa kasihan kepada bayinya karena anggapan asupannya kurang, karena harus dibagi dengan bayi yang sekarang dikandung. Ketika bayi rewel dan menangis, ibu beranggapan bahwa hal tersebut identik dengan kondisi lapar dan haus.

"Awale niku kulo hamil panggah kulo susoni, tapi larene tetep rewel, mesakne, nggih terus niku kalih make diutus nyadur ndamel susu formula kaleh banyu gulo, tirose jik luwe kui. Nah semenjak niku pun mboten kulo paringi ASI."

(Awalnya itu meski saya hamil tetap saya susui, tapi anaknya tetap rewel, kasihan, ya itu terus sama ibu saya disuruh menyadur menggunakan susu formula dan air gula, katanya masih lapar itu. Nah semenjak itu tidak saya kasih ASI)

(Tr, ibu balita, 30 tahun)

"Soale wis enek adike, gak iso warek, la kebanyakan ngunu i mbak sing kesundulan wi, mergo rasane panas, susune gak enek gizine bongkah encer..."

(Soalnya sudah ada adiknya, gak bisa kenyang, Iha kebanyakan seperti itu mbak yang kesundulan itu, karena rasanya panas, susunya gak ada gizinya, encer...)

(Tm, ibu balita, 35 tahun) 
Pola asupan yang turun-temurun turut menjadi tantangan tersendiri. Ditemukan bahwa tinggal serumah dengan orang tua (nenek balita) turut menjadi hambatan bagi ibu dalam memberikan ASI Eksklusif pada bayinya.

"...pengenku tak paring ASI tok mbak, tapi piye, lek pas tak tinggal dilut sing nunggu nggih mbahe. Pas rewel kalih mbahe disukani banyu gulo, lek mboten ngoten ngih toyo petak."

(Saya sih kepingin hanya memberi ASI saja mbak, tapi bagaimana ya, ketika saya tinggal sebentar yang menunggu ya neneknya. Ketika rewel sama neneknya dikasih air gula, kalautidak begitu ya air putih)

(Dk, ibu balita, 24 tahun)

Tidak hanya asupan berbentuk cair, bayi 0-6 bulan di Desa Kepung juga sudah dikenalkan dengan makanan padat. Pemberian makanan padat ini dilakukan dengan tekstur yang dihaluskan terlebih dahulu.

"Mlebet usia limang wulan pun kulo dulang pisang kalih $S^{*} N$ niku, soale kan bade poso, wedi lek ASI-ne kirang."

(Masuk usia lima bulan sudah saya suapi pisang dengan $\mathrm{S}^{*} \mathrm{~N}$ itu, soalnya kan mau puasa, takut kalau ASI-nya kurang)

(Dk, ibu balita, 24 tahun)

"Umur patang wulan pun kulo kenalne kalih pisang, kulo kerok."

(Umur empat bulan sudah saya

kenalkan pisang, saya kerok)

( $T r$, ibu balita, 30 tahun)

Selain pisang, bayi juga sudah dikenalkan dengan makanan orang dewasa. Pola pemberiannya sama dengan pisang, yaitu dengan cara dilumat terlebih dahulu.

"Sayur niku mboten purun blas, maeme sak nyuwune larene mbak. Senengane niku nggih namung sekul kalih duduh bening kalih lawuhe niku nggih mboten mesti, kadang telur, kadang nggih tahu tempe, kadang kalih krupuk. Ayam kalih ikan jarang, kados dereng saget mamah ngoten lo, namung disesepi."

(Sayur itu tidak mau sama sekali, makannya sesuai permintaan anaknya mbak. Kesenangannya itu ya hanya nasi dengan kuah bening dengan lauk yang tidak pasti, terkadang telur, terkadang ya tahu tempe, terkadang dengan kerupuk. Ayam dan ikan jarang, sepertinya belum bisa mengunyah begitu lo, hanya dihisap-hisap)

(Dk, ibu bayi, 24 tahun)

"Maeme niku nggih sekul kalih sayur bening. Wortel niku lo larene seneng, 'Mak nak mak.' Seringe lawuhe tahu tempe, telur mboten nate, umpami purun nggih namung putihe mawon seng dimaem. 'Moh moh mak, ndak inak.' Lek kulo pekso nggih dimuntahaken. Ikan nggih jarang pol, paling lek enten sing nyukani, mboten cukup mbak yatrane (untuk beli)."

(Makannya itu ya nasi dengan sayur bening. Wortel itu lho anaknya senang, 'Mak enak mak.' Seringnya lauk tahutempe, telur tidak pernah, seumpama mau ya hanya bagian putihnya saja yang dimakan. "Ndak mau mak, ndak enak.' Kalau saya paksa ya dimuntahkan. Ikan ya jarang sekali, mungkin kalau ada yang memberi, tidak cukup uangnya)

(Sr, nenek bayi PN, 48 tahun)

"Seringe nggih niku, nasi kalih sayur sop, sayur bening bayem, lawuhe ndamel tahu tempe, kadang nggih tumbas bakso lewat niku. Kadang lek pas bosen tahu tempe nggih tumbas ati ayam, tapi nggih jarang."

(Seringnya ya itu, nasi sama sayur sop, syur bening bayem, lauknya menggunakan tahu, tempe, terkadang ya beli bakso yang lewat itu. Terkadang kalau pas bosan tahu tempe ya beli hati ayam, tapi ya jarang)

(Tr, Ibu bayi , 30 tahun)

Berdasarkan hasil pengamatan, jenis asupan makanan lain yang diberikan adalah jajanan yang mengandung zat adiktif. Jajanan semacam $\mathrm{Ch}^{*} *_{\mathrm{i}}$ dan jenis lain yang ber-vetsin tinggi kerap diberikan saat anak rewel.

"Maeme angel, tapi njajane nemen mbak. Nggih kadang sosis, kulo tumbasaken cilok, kadang nggih nyuwun roti, chi*i-chi*i limang atusan ngoten niku lo. Nopo malih kalih maeman sing legi legi nopo minuman berasa niku, remene jan mboten kenging dipenging, malah ngamuk nangis mbak."

(Makannya susah, tapi beli jajannya sering mbak. Ya terkadang sosis, saya belikan cilok, terkadang ya minya roti, chi*i-shi*i lima ratusan seperti itu lho. Apa lagi dengan jajanan yang manismanis apa minuman rasa-rasa itu, sukanya sampai tidak bisa dicegah, malah marah-marah nangis mbak)

(Dk, ibu bayi, 24 tahun)

Pola pemberian makan pada balita harus dilakukan dengan tepat agar gizi balita bisa tercukupi dengan baik. Peraturan Menteri Kesehatan menganjurkan bahwa balita usia 0-6 bulan hanya cukup diberikan ASI eksklusif atau ASI saja tanpa adanya asupan lain, karena ASI yang diproduksi ibu selama 24 jam tersebut yaitu kurang lebih $750-1000 \mathrm{ml} /$ hari dapat 
menghasilkan energi 500-700 kkal/hari ${ }^{14}$. Setiap $100 \mathrm{ml}$ ASI mengandung energi protein sebesar 1,30 gram, lemak sebesar 4 gram dan 7,11 gram untuk karbohidrat $^{15}$. Jadi, jika dihitung per hari kandungan gizi yang dihasilkan ASI selama 24 jam sudah setara dengan standar angka kecukupan gizi yang telah diatur pada Permenkes Nomor 75 Tahun 2013, dimana mana balita dengan usia 0-6 bulan membutuhkan angka kecukupan gizi sebesar 550 kkal untuk energi, 12 gram untuk protein, 34 gram untuk lemak dan 58 gram untuk karbohidrat ${ }^{15}$.

Setidaknya ada 14 risiko buruk yang dihimpun dari beberapa penelitian tentang pemberian makanan tambahan sebelum bayi berumur 0-6 bulan. INFACT Canada menyebutkan bahwa bayi bisa terkena risiko asma, alergi, penurunan perkembangan kognitif, penyakit saluran pernafasan, infeksi formula yang terkontaminasi, kanker, penyakit kronis, diabetes, penyakit kardiovaskuler, obesitas, infeksi gastrointestinal, otitis media dan infeksi telinga, efek samping kontaminasi lingkungan, dan kematian ${ }^{16}$.

Pemberian makanan pendamping ASI (MP-ASI) dapat diberikan apabila ASI saja tidak cukup untuk memenuhi kebutuhan bayi yaitu ketika usia bayi masuk 6 bulan. Masuk usia 6 bulan, bayi mulai diperkenalkan dengan MP-ASI dan meneruskan pemberian ASI sampai usia 24 bulan. Ada beberapa hal yang harus diperhatikan dalam pemberian makanan pada bayi dan anak antara lain usia anak, frekuensi pemberian makanan dalam sehari, jumlah pemberian makanan atau porsi untuk sekali makan, tekstur makanan, variasi makanan, pemberian makanan secara aktif atau responsive pada anak dan selalu menjaga kebersihan ${ }^{14}$. Pada usia 6 sampai 9 bulan bayi mulai diperkenalkan dengan MP-ASI berbentuk lumat halus karena bayi sudah memiliki reflek mengunyah. Pada usia 9 sampai 12 bulan bayi mulai diperkenalkan dengan makanan lembek yaitu berupa nasi tim atau bubur saring dengan frekuensi dua kali sehari. Nasi tim bayi harus diatur secara berangsur. Pada usia 12-24 bulan makanan yang diberikan lambat laun mendekati bentuk dan kepadatan makanan keluarga ${ }^{15}$.

\section{"Air Gula yang Menyehatkan"}

Air gula sudah menjadi pangan yang umum diberikan pada bayi di Desa Kepung. Usia awal pemberian air gula menurut setiap informan berbedabeda,ada yang air gulanya diberikan mulai dari sejak lahir, ada juga yang mulai sejak usia bayi satu bulan dan ada juga yang diberi hanya ketika ibu sedang keluar saja. Variasi frekuensi dan porsi pemberian air gula setiap informan juga berbeda, mulai dari setengah gelas teh kecil sampai yang satu botol ukuran $120 \mathrm{ml}$ sekali minum.

"Satu bulan lebih lah mbak kiro-kiro, pokok aku jik awal hamil. Sadurane susu SG* 3 botol sehari kinten-kinten geh 90-120 ml niku. Banyu gulone ping kalih, enjing kalih siang, nggih ndamel botol susu niku. Lek gulone 1,5 sendok bebek plastik niku."

(Satu bulan lebih lah mbak kira-kira, pokoknya pas saya awal hamil. Sadurannya susu SG* 3 boto; sehari, kira-kira ya 90-120 ml itu. Air gulanya dua kali, pagi dan siang, ya memakai botol susu itu. Kalau gulanya 1,5 sendok plastik itu)

( $T r$, ibu balita, 30 tahun)

" ...umur satu bulan niko, pas kulo tinggal medal kontrol niko, seng nyukani mbahe niku to, tapi nggih kedik, namung setengah gelas teh cilik, gulone setengah sendok the. Niku ae nggih mboten telas. Lek kulo teng griyo nggih panggah kulo sukani ASI..."

(...umur satu bulan itu, pas saya tinggal keluar kontrol itu, yang memberikan neneknya itu to, tapi ya sedikit, hanya setengah gelas the kecil, gulanya setengah sendok teh, itu saja ya tidak habis. Kalau saya di rumah ya tetap saya kasih ASI)

(Dk, ibu balita, 24 tahun)

"Sedinten nggih 3-4 botol $120 \mathrm{ml}$ mboten mesti, gulone sekedik setengah sendok teh mbak. Nggih nasine 2 sendok makan dicampur karo pisange dikerok setunggel sak maeman, sedino seringe ping kalih paring ndulang nduke, lek pas bayi nggih sepindah ndulange."

(Sehari ya 3-4 botol $120 \mathrm{ml}$ tidak pasti, gulanya sedikit setengah sendok the mbak. Ya nasinya 2 sendok makan dicampur dengan pisang dikerok satu biji sekali makan, sehari seringnya dua kali disuapin anaknya, kalau pas bayi yang sekali nyuapinnya)

(Sr, ibu balita, 48 tahun)

Pemberian air gula pada bayi di Desa Kepung dipercaya sebagai sesuatu hal yang memberikan dampak baik pada bayi. Air gula diyakini dapat menyehatkan. Keyakinan ini berkembang tidak hanya pada masyarakat kebanyakan, tetapi juga dibenarkan oleh tokoh masyarakat.

"...kirangan nggih mbak, hehe, make sing maringi, coro, o ben sehat..."

(Tidak tahu ya mbak, hehe... ibu saya yang memberikan, caranya biar sehat) (Tr, ibu balita, 30 tahun)

"Banyu gulo iku lek wong mbiyen enek sing omong diparingne pas mari lahir, lek gak ngunu diwei madu. Kan banyu susune durung metu biasane lek mari lahir. Dadi bayi lek diwei banyu gulo iku seng asale nangis mundak meneng, mergo warek, gak lemes, daya tahan tubuhe nambah, selain iku yo ben sehat. Anakku empat kabeh tak ombeni banyu gulo sampe rong taun, sehatsehat kabeh..." 
(Air gula itu kalau orang dulu ada yang mengatakan diberikan ketika baru lahir, kalau tidak begitu ya diberi madu. Kan air susu ibunya belum keluar biasanya ketika baru lahiran. Jadi bayi ketika diberi air gula yang awalnya nangis menjadi diam, karena kenyang, gak lemas, daya tahan tubuhnya meningkat, selain itu ya biar sehat. Anak saya empat semua tak minumi air gula sampai dua tahun, sehat-sehat semua)

(En, tokoh masyarakat/agama, 52 tahun)

Air gula ditemukan menjadi hal yang umum diberikan pada bayi di Desa Kepung. Berdasarkan hasil wawancara berkembang keyakinan bahwa air gula memiliki khasiat yang bisa mengenyangkan, membuat daya tahan tubuh meningkat, dan membuat sehat. Health belief (keyakinan) pada jenis makanan tertentu untuk bayi juga ditemukan pada Suku Muyu di Boven Digoel, Papua. Masyarakat Suku Muyu memberikan larutan sagu untuk bayinya. Selain itu, menginjak usia 45 bulan bayi Muyu juga sudah disuapi dengan makanan keras yang telah dilumat. Pola asupan ini mereka sebut sebagai toman tinggi $i^{17}$. Health belief lain terkait makanan yang sering diangkat oleh peneliti adalah makanan pantangan (food taboo), terutama pada ibu hamil, terkait dengan keyakinan pada dampaknya yang diyakini baik terhadap kesehatan ibu dan janinnya ${ }^{18,19,20}$. Budaya dinilai memiliki pengaruh yang kuat terhadap keputusan untuk mengkonsumsi makanan tertentu atau tidak $^{20,21,22}$

Sudah ada upaya yang dilakukan oleh pemerintah (Puskesmas) untuk memutus pola asupan turun temurun tersebut. Puskesmas di Indonesia secara umum telah melaksanakan program kelas ibu hamil ${ }^{23,24}$. Melalui program ini Puskesmas dapat memodifikasi atau menambah materi terkait asupan untuk bayi sampai dengan balita. Calon ibu balita merupakan sasaran intervensi paling tepat. Hasil beberapa penelitian menemukan bahwa pengetahuan dan pendidikan ibu sangat berpengaruh terhadap status gizi anak ${ }^{25,26,27}$.

Hasil penelitian menemukan bahwa nenek bayi, atau ibu dari ibu bayi, ditemukan turut menjadi hambatan perilaku kesehatan positif dari ibu bayi. Temuan merupakan konsekuensi pola asupan turuntemurun yang berlaku sebagai budaya dalam keluarga ${ }^{28,29}$. Selain memodifikasi materi kelas ibu hamil, Puskesmas juga bisa memperluas peserta kelas ibu hamil dengan menambahkan suami, nenek, atau orang lain yang akan sering mendampingi bayi nantinya. Langkah ini diperlukan untuk memberikan persepsi yang sama pada keluarga terdekat yang dinilai bisa mempengaruhi pola asupan pada balita. Terbukti sudah ada hasil penelitian tentang edukasi ke keluarga balita bahwa bisa memperbaiki asupan balita ${ }^{30}$.

Hasil penelitian menemukan bahwa tokoh masyarakat masih memiliki persepsi yang sama dengan masyarakat tentang pola asupan untuk bayi di Desa Kepung. Temuan ini menjadikan tokoh masyarakat masuk dalam kategori kelompok sasaran intervensi yang tepat. Tokoh masyarakat, apalagi di wilayah rural, merupakan orang kunci untuk membuat perubahan yang masif atau berskala besar, dan permanen di masyarakat. Beberapa hasil penelitian menemukan bahwa menempatkan tokoh sebagai agen perubahan akan membuat tingkat keberhasilan intervensi menjadi lebih tinggi ${ }^{31,32}$.

Penelitian ini merupakan penelitian kualitatif, sehingga hasil studi ini memiliki keterbatasan hanya berlaku di lokasi studi. Fenomena yang ditemukan di lokasi studi tidak dapat digunakan atau dianggap sama untuk wilayah lain. Studi yang dilakukan juga terbatas pada eksplorasi pola asupan pada bayi. Studi tidak melihat lebih jauh tentang dampak sebagai akibat pola asupan tersebut.

\section{KESIMPULAN}

Berdasarkan hasil penelitian dan pembahasan dapat disimpulkan bahwa pola asupan pada bayi di Desa Kepung sangat bervariasi. Tidak hanya ASI saja, bayi juga sudah diberikan makanan orang dewasa yang dilembutkan. Masyarakat di Desa Kepung juga memiliki kebiasaan memberikan bayinya air gula.

Menyikapi fenomena pola asupan bayi di Desa Kepung ini, maka Puskesmas perlu melakukan intervensi untuk memutus kebiasaan turun-temurun yang kurang tepat dalam asupan pada bayi tersebut. Puskesmas dapat menambahkan materi soal kecukupan gizi bayi dalam kelas ibu hamil. Puskesmas juga perlu melakukan pendekatan pada tokoh masyarakat dan memberi pemahaman yang benar. Tokoh masyarakat perlu didorong untuk menjadi agen perubahan terkait asupan makanan pada bayi.

\section{ACKNOWLEDGMENT}

Penulis mengucapkan terimakasih kepada mahasiswa yang membantu dalam pengumpulan data dan teman dosen atas masukan, pendapat maupun saran dalam perancangan dan penyelesaian penulisan artikel ini.

\section{REFERENSI}

1. Datesfordate, A. H., Kundre, R. \& Rottie, J. V. Hubungan Pemberian Makanan Pendamping Air Susu Ibu (MP-ASI) dengan Status Gizi Bayi pada Usia 6-12 Bulan di Wilayah Kerja Puskesmas Bahu Manado. J. Keperawatan 5, 1-7 (2017).

2. World Health Organization/Unicef. Pelatihan konseling menyusui modul 40 jam: panduan peserta. (WHO Jakarta Office/Unicef, 2011).

3. Widaryanti, R. Cegah Masalah Gizi Anak dengan Sosialisasi Pemberian MakananBayi dan Anak. PengabdianMu J. IIm. Pengabdi. Kpd. Masy. 4, 94-98 (2019).

4. National Institute of Health Research and Development of The Indonesia Ministry of Health. The 2018 Indonesia Basic Health Survey (Riskesdas): National Report. (2019).

5. Arsyati, A. M. \& Rahayu, Y. T. Pola Asuh Budaya Pemberian Makanan Pendamping Asi (MP-ASI) pada Bayi Usia Kurang dari 6 Bulan di Desa Leuwibatu Rumpin. HEARTY 7, 1-7 (2019).

6. Adriani, M. \& Kartika, V. Pola Asuh Makan pada 
Balita dengan Status Gizi Kurang di Jawa Timur, Jawa Tengah dan Kalimantan Tengah, Tahun 2011. Bul. Penelit. Sist. Kesehat. 16, 185-193 (2013).

7. Amperaningsih, Y., Sari, S. A. \& Perdana, A. A. Pola Pemberian MP-ASI pada Balita Usia 6-24 Bulan. J. Kesehat. 9, 310-318 (2018).

8. Gustini, S., Masyitah, S. \& Aisyiyah, N. Determinan tumbuh kembang pada bayi 6-12 bulan di wilayah kerja puskesmas pancur kota serang tahun 2017. J. Formil KesMas Respati 4, 79-88 (2019).

9. Langås-Larsen, A. et al. "We own the illness": a qualitative study of networks in two communities with mixed ethnicity in Northern Norway. Int. J. Circumpolar Health 77, Article number 1438572 (2018).

10. Von Gaudecker, J. R. Challenges in Conducting Ethnography among Hidden Populations in Rural South India. J. Neurosci. Nurs. 50, 351-355 (2018).

11. Olthof-Nefkens, M. W. L. J. et al. Improving Communication between Persons with Mild Dementia and Their Caregivers: Qualitative Analysis of a Practice-Based Logopaedic Intervention. Folia Phoniatr. Logop. 70, 124-133 (2018).

12. Sánchez-Gómez, M. C., Iglesias-Rodríguez, A. \& Martín-García, A. V. Software as a facilitator of quality processes in social sciences research. Qual. Quant. 52, 2515-2533 (2018).

13. Eleftherakos, C. et al. 'I prefer dying fast than dying slowly', how institutional abuse worsens the mental health of stranded Syrian, Afghan and Congolese migrants on Lesbos island following the implementation of EU-Turkey deal. Confl. Health 12, Article number 38 (2018).

14. Kementerian Kesehatan RI. Praktik Pemberian Makanan dan Anak (PMBA) untuk Perubahan Perilaku Pemenuhan Asupan Gizi Anak dalam Upaya Pencegahan Stunting. (Kementerian Kesehatan RI., 2018).

15. Soetjiningsih. ASI Petunjuk Untuk Tenaga Kesehatan. (EGC, 2012).

16. INFACT Canada. Fourteen Risks of Formula Feeding. A brief annotated bibliography. (2002).

17. Laksono, A. D. Anyiman: Studi Etnografi Makanan Suku Muyu (Anyiman: Ethnographic Study of Muyu Tribal Foods). (PT Kanisius, 2015).

18. Chakona, G. \& Shackleton, C. Food taboos and cultural beliefs influence food choice and dietary preferences among pregnant women in the eastern Cape, South Africa. Nutrients 11, Article number 2668 (2019).

19. Iradukunda, F. Food taboos during pregnancy.
Health Care Women Int. in press, 1-10 (2019).

20. Tobing, V. Y., Afiyanti, Y. \& Rachmawati, I. N. Following the cultural norms as an effort to protect the mother and the baby during the perinatal period: An ethnographic study of women's food choices. Enferm. Clin. 29, 831836 (2019).

21. Triratnawati, A. Food taboos and codes of conduct for pregnant women at Mount Sindoro, Wonosobo district, Central Java, Indonesia. Stud. Ethno-Medicine 13, 22-32 (2019).

22. Pineros-Leano, M., Tabb, K., Liechty, J., Castañeda, Y. \& Williams, M. Feeding decisionmaking among first generation Latinas living in non-metropolitan and small metro areas. PLOS One 14, Article number e0213442 (2019).

23. Puspita, Y. \& Susanti, E. Counseling for Pregnant Women Classes about P4K (Penyuluhan Kelas Ibu Hamil tentang P4K). J. Media Kesehat. 10, 78-83 (2017).

24. Chabibah, N. \& Khanifah, M. Layanan Kesehatan Ibu Hamil Berkesinambungan. GEMASSIKA 3, 69-82 (2019).

25. Nirmala, I. R., Februhartanty, J. \& Wiradnyani, L. A. A. Maternal attributes are positively associated with feeding practices of children aged 2-5 years in West Java, Indonesia. Malays. J. Nutr. 22, 191-205 (2016).

26. Vikram, K. \& Vanneman, R. Maternal education and the multidimensionality of child health outcomes in India. J. Biosoc. Sci. 1-21 (2019). doi:10.1017/S0021932019000245

27. Laksono, A. D., Ibad, M., Mursita, A., Kusrini, I. \& Wulandari, R. D. Characteristics of mother as predictors of stunting in toddler. Pakistan J. Nutr. 18, 1101-1106 (2019).

28. Aeni, N. Pantangan dalam Perawatan Kehamilan (Studi di Desa Pakem dan Jrahi Kabupaten Pati). J. Litbang 10, 143-151 (2014).

29. Sjarkawi, G., Novrinda, H. \& Bahar, A. PENGARUH TRADISI NASI PAPAH TERHADAP RISIKO TERJADINYA EARLY CHILDHOOD CARIES DI DESA SENYIUR LOMBOK TIMUR. J. B-Dent 2, 51-59 (2015).

30. Sadli, M. Hubungan Sosial Budaya dan Peran Petugas Kesehatan dengan Perilaku Pemberian MP-ASI Dini pada Bayi Usia 0-6 Bulan. J. Kebidanan 11, 15-23 (2019).

31. Rashid, T. Theatre for Community Development: Street Theatre as an Agent of Change in Punjab (Pakistan). India Q. 71, 335-347 (2015).

32. Laksono, A. D. et al. Sociogram Analysis for Determining Agents of Change; Case Study of the Desa Sehat Berdaya Program. Bull. Heal. Syst. Res. 22, (2019). 